\title{
Mother Tongue Teaching at School Comparison of French and Turkish Models*
}

\author{
Ebubekir Bozavlı \\ Correspondence: Ebubekir Bozavl1, Assistan Professor, Departement of Foreign Language Teaching, Atatürk University, \\ Turkey.
}

Received: February 16, 2017

doi:10.11114/jets.v5i4.2223

\author{
Accepted: March 8, 2017 \\ Online Published: March 10, 2017 \\ URL: https://doi.org/10.11114/jets.v5i4.2223
}

\begin{abstract}
Like speaking, two other important aspects of language are reading and writing. Speaking is acquired unconsciously in public while other two skills are learned at school and contribute to life-long speaking skills. The present research is to analyze mother tongue teaching at school and compare two different models, one in France, a developed European country and the other in Turkey, a developing and still a candidate country to European Union. The research has been conducted by using document analysis and interview method. Mother tongue teaching textbooks are the samples of the study, those used as of primary school in Turkey and those used as of kindergarten in France. During interview, discussion-like interview has been conducted. Interview was conducted face-to-face with Turkish teachers in Turkey while it was through a questionnaire online that French teachers were interviewed. The data obtained were interpreted by descriptive method. In both countries, rather than similarities, differences were found in mother tongue teaching at schools. These differences result from both education systems and classroom activities. French teachers are more positive about mother tongue teaching activities in classroom compared to Turkish teachers and think more universally. Turkish teachers complain more about lack of physical equipment at this level.
\end{abstract}

Keywords: school, mother tongue teaching, speaking, reading, method, proficient individual

\section{Introduction}

Language is one of the important values of mankind. Seeming simple, it has a more complicated structure. It is multidimension from phonetic and grammatical system to sociological, psychological and cultural components. Famous French linguist Ferdinand de Saussure (1967) defines language as a system while Yuen Ren Chao (1970) as a whole of habits, a system of communication and compromise and a social institution. Language is divided into written and oral language. Written language has emerged as a result of the use of a language based on a dialect or accent. Written language is a common language. Oral language has various traits of enounciation and is different from written language (Sarıca, 2005). Individual employs speaking skill to communicate orally and convey a discourse and a message. Oral language is learned implicitly. It is acquired without any goal of learning, naturally and unconcious of what is learned. The only need is a social environment. Child passes through three stages while learning the language used by adults: cry, babbling and proper language (Delacroix, 1930). He passes through a stage where he asks questions and wonders about the names of the objects around him and increases the number of vocabulary. Until primary school, mother tongue learned unplanned turns into a systematic structure after that. This systematic teaching is a stage where mother tongue rules are taught. Child learns written language together with phonetic system and grammatical rules. Written language is a formal dimension of mother tongue teaching. In other words, child learning the informal aspect of language learns the formally the written side. This separates acquisition from learning concepts. Mother tongue starting with acquisition proceeds with learning. In this vein, the aim of the paper is to analyze formal teaching of mother tongue. We target comparison of mother tongue teaching model in France, one of the most developed members of European Union with that of Turkey, still developing and candidate country of EU.

\section{Methodology}

The research is based on document analysis and interview. Document analysis, generally used by anthropologists,

\footnotetext{
*This article was extracted from a master's thesis written by the author Bozavlı Ebubekir, entitled "L'enseignement du français et du turc comme langue maternelle en première année".
} 
historians and linguists is comprised of analysis of written documents containing information on the phenomena researched (Yıldırım and Şimşek, 2000). Mother tongue teaching textbooks used in Turkey as of first grade in primary school and kindergarten in France are the samples of the study. In this respect, "Türkçe Ders Kitabı (Turkish Language Maincourse book), Okuma Yazma Öğreniyorum (I learn reading and writing), Türkçe Öğretimi Çalışma Kitabı (Turkish language workbook)" related to Turkish in Turkey (Tortup and al, 2005) two volume "Justine et Compagnie" (Youenne and al, 2000) maincourse books for French were used for analysis. For interview, discussion like interview was conducted. This approach is used generally in researches where the researchers participate in the setting as participant observer (Giroux and Tremblay, 2002). Questions are asked spontaneously and the flux of speaking goes on naturally. By interviewing a couple of teachers and administrators in France and Turkey, and communicating with teachers teaching mother tongue on forums and blogs, we tried to theorize the practical side of teaching. In addition, a questionnaire related to classroom activities, methods and techniques used and assessment with open-ended questions was administered on French and Turkish teachers. The questionnaire was conducted face-to-face to Turkish teachers and online with French colleagues. The data obtained were designed in accordance with the themes beforehand and interpreted.

\section{Results}

\subsection{General Overview on Turkish and French Education Systems}

Education aims to develop in a general sense academic competences, physical and emotion behaviour of individuals and help them with knowledge and skills in different disciplines. Turkish education history, though dating back to ancient periods, has taken a concrete shape together with the foundation of the republic of Turkey in 1923 and crucial reforms not only in social life but also in education have been witnessed since then. There are still reforms and modifications in education from time to time. For instance, the most radical change was done in 1997 in elementary education system. Elementary and primary educations were combined, thereby making 5 year obligatory education 8 years and high school education was extended one year and the duration became 4 years. Particular changes were made in textbooks and mother tongue teaching methods. "Sentence based teaching method" was repealed claiming that it barred critical and global thinking skills of learners and "phonetic based teaching method", used commonly in European countries was adopted. Kindergarten is not obligatory in Turkey and the age of schooling is 7. In French education system, Jules Ferry is a turning point. Fundamentals of French education were founded with elementary education principles during her period and myriad novelties were adopted. One of them was to establish primary school and a library in kindergarten as well as a resource centre. In addition, a good many privileges were provided to education institutions and kindergarten was put into primary school. In order to increase student achievement level, parents were asked to participate actively in schooling.

\subsection{Mother Tongue Teaching in Elementary School}

Child is surrounded with language in the moment he comes to the world. First, he hears what is spoken around him then starts to speak after passing through certain stages. Family and environment take responsibility for him to improve his speaking and use the language properly. He commences to use the language learned spontaneously until school where he starts to learn systematically. In other words, he has no certain program, nor a teacher or a textbook when learning speaking. By the time he learns written language, all of the components are practiced. In systematic mother tongue teaching, oral language is prioritized. Turkish education system involves five basic skills in this respect: listening, verbal expression, reading, writing and visual reading/perception. In French education system, a hierarchy of mastering oral language, communication, reading and writing is common in mother tongue teaching. Turkish and French education differs in certain aspects in terms of mother tongue teaching. In France, kindergarten and primary school are complementary and supportive (Menf, 2004). Preparations for mother tongue such as listening reading and writing and general education procedure start in kindergarten in France. Listening is fundamental linguistic development process. For students to participate in listening activities, their physical and cognitive preparedness is paramount. Teachers are supposed to teach and make students practice appropriate sitting position for listening. Preparations for reading may involve such activities as sitting, opening and holding books, visual reading and encouraging reading while preliminary writing practices consist of developing hand muscles, proper hold of pencil, regular notebook writing (Keskinkılıç et al, 2005). Thus, students start their first year at primary school prepared by means of authentic activities done before. In Turkey, since individuals do not have a different opinion on kindergarten and attending kindergarten is no as common as in France, both preparations and authentic activities are conducted in the first year at primary school. French students are preceding Turkish peers.

\subsection{Methods Used in Teaching Mother Tongue at School}

One of the prominent elements in teaching mother tongue at school is the method or techniques used in teaching mother tongue as a written language. Inductive and deductive methods have been used in teaching reading and writing for years. 
Inductive method follows as of the smallest unit, phoneme to syllable, word and sentence. Deductive method, on the contrary, follows word, syllable and phoneme system. In Turkey, the use of both deductive and inductive methods is quite common. "Sentence based method" used for a long time in Turkey was replaced by "phoneme based method", a method conforming to Turkish vocal structure and commonly used in Europe since the former was not contributive to the development of students' reading and critical thinking skills. Therefore, in education phoneme has become the starting point instead of sentence. As to the French education system, a third method, also called "mixed or interactive" in addition to the above mentioned methods, which contain traits of these methods, exists. However, in practice we observe differences in Turkish and French systems. In Turkey, a method designed by authorities must be used all over Turkey. Today, it is the phoneme based mother tongue teaching. Teachers are not allowed to use another method together or in addition to this method while in France teachers are given flexibility to use other methods, too. Such a use would be determined by collaboration of teachers at school. The principal reason for such a practice is individual differences between students. Since the classrooms are not homogeneous, each student differs in learning rate, willingness, perception level. In a scientific research conducted in Turkey on teachers, it was found that teachers agreed that in Turkey, people should adopt the system used in France. Teachers state that considering individual differences in teaching reading and writing, for disadvantaged students, mixed method should be used. In mixed method, both sentence based and phoneme based methods are used at the same time. So, the mixed method is preferred in contribution to increase their level of reading and writing, communication and catch-up with other students (Tok, 2001).

\subsection{In-class Approaches in Mother Tongue Teaching}

Today, the world is where changes are inevitable in every discipline and knowledge modifies its shape. It is high time that we also change our perspectives and opinions. Such transformations are observed in education, too. Pedegogists, researchers question approaches and proposes novelties for better education. In mother tongue teaching, teaching in teams, autonomy in learning and questioning in mother tongue teaching as well consideration of individual differences and game are regarded as contemporary practices.

\subsection{Mother Tongue Teaching in Teams}

Team-work is considered preliminary in freshman students' socialization, exchange of information among them. Discussions, meeting to exchange information enrich group dynamism, develop individual potential and help students solve complicated network of knowledge (Giordan, 2002). By tradition approach, groups are comprised generally heterogeneous or homogeneous. Fijalkow $(1999 ; 36-41)$ points out that groupings in mother tongue teaching contribute to the increase in rate of learning since they are based on contemporary quality and social relations. This approach rests not on students' academic abilities but on their social relations. Students decide on their own with whom they make teams while groupings. Student is free to select his peer. Based on their choices, teacher composes groups in four or five and he coordinates groups and keeps timing by joining the groups when in need. One group studies on its own while others wih teacher and such a system functions by turns. Contrary to Turkey, in France, teaching in groups has become a tradition. Team-word is strongly encouraged. Even the whole classroom could be regarded as big team. This is a social teaching method. This shows us that students learn to be adoptive to the community when they are older. They become more integrative rather than exclusionist. They never exclude other but rather accept their presence. In a sense, foundations of modern and democratic society are laid by teaching systems. They can solve problems independently in a reconciliatory manner. They gradually become autonomous.

\subsection{Autonomy and Mother Tongue Teaching}

Working in autonomy is one of the distinguishing values of educational understanding. In a world where knowledge very often changes within short intervals, access to new knowledge and knowing to get it without any dependence on others help individuals improve their skills in research and will to learn. Learner takes the responsibility for gaining knowledge and learns to instruct himself. This way would give him internal motivation. Autonomy or being autonomous does not necessarily mean leaving student alone or abandon him. Rather, teacher is among the students like wagons of a train and in service of the learners (Giordan, 2002). In today's Turkey, there is an understanding that teacher is centered in mother tongue teaching at school and the learner is dependent on the teacher in learning process. Teacher is more dominant while student is more passive. This approach leads students more to a rote-learning education. In recent years, although a more student centered understanding has been adopted in theory, unfortunately in practice this understanding is not still seen. In France, individual learning areas called centers of documentation where they can collect "documents and information" and where they can also do research independently at schools have been found. Dependence of learner on teacher is being diminished. Fijalkow states that the activities to be adopted even in mother tongue learning should be selected by the learners themselves and the imposed activities would take them apart from their learning motivation. Learner neither needs to help from other adults nor expect to be eulogized. The individual learning to become autonomous would certainly demonstrate traits of autonomy in other classrooms. 


\subsection{Mother Tongue Teaching by Questioning Consciousness}

It is highly important for learner to ask questions while learning and question whatever he learns. This behaviour renders it possible to reach knowledge more logically and absolutely. Each piece of knowledge is an answer to a question and questioning is a fundamental of learning. It activates knowledge (Giordan, 1998). To start mother tongue teaching by questioning could possibly trigger learners' motivation. Teaching reading and writing in primary school should begin by asking such questions as "what is reading for? What does an individual get from reading? In what parts of life is it beneficial?" because teaching mother tongue at school differs in some ways from learning it in daily life. Child is confronted with oral and written language dilemma. Written language is that is at thought and mental design level. That may also involve more abstract traits compared to oral language. There is an interlocutor infront of you and language in this way concretizes. In written language, one may even not be able to find such an interlocutor. It is imaginary and schematic. Likewise, spoken language is learned informally while written language is learned formally. While child perceives the oral language as a necessity to communicate, he may not be able to perceive for what reasons written language has been used (Bernardin, 1997). Questionning culture is an obligation from this perspective in mother tongue teaching. Unlike France, it is pretty hard to explain that in this culture of literature is hardly any such a practice in Turkey and aims to help students access to this skill. In curricula, we just start to make emphasize on this field and indeed, in practice, individuals might take long to gains such skills.

\subsection{Role of Individual Differences in Mother Tongue Teaching}

Man is born into various skills, potential and competence. Each individual is different mentally, socially from one another. These discrepencies show up at school in formal education. Some students are touchy, aggressive, passive, unmotivated and introverted while others tend to be willing to learn, active, creative and responsible for their duties. The classroom becomes heterogeneous with distinct characters. Teacher is supposed to take into considerations such divergence and reply to each individual's need. People do not possess the same views. If they are known about their competences, they may be able to solve their problems in learning (Keskinkılıç, 2005). The role of family and social environment cannot be denied in development of both social and individual capacity and mental capabilities. Child growing up interested in reading is always ahead of others in reading and writing. In this respect, both French and Turkish education systems take into account individual differences. Teachers deal with students having difficulty in learning and make efforts to bring them to the level of other students. Unlike Turkish teachers, French teachers were observed to collaborate more with their colleagues and take more responsibility for guidance.

\subsection{Mother Tongue Teaching with Games}

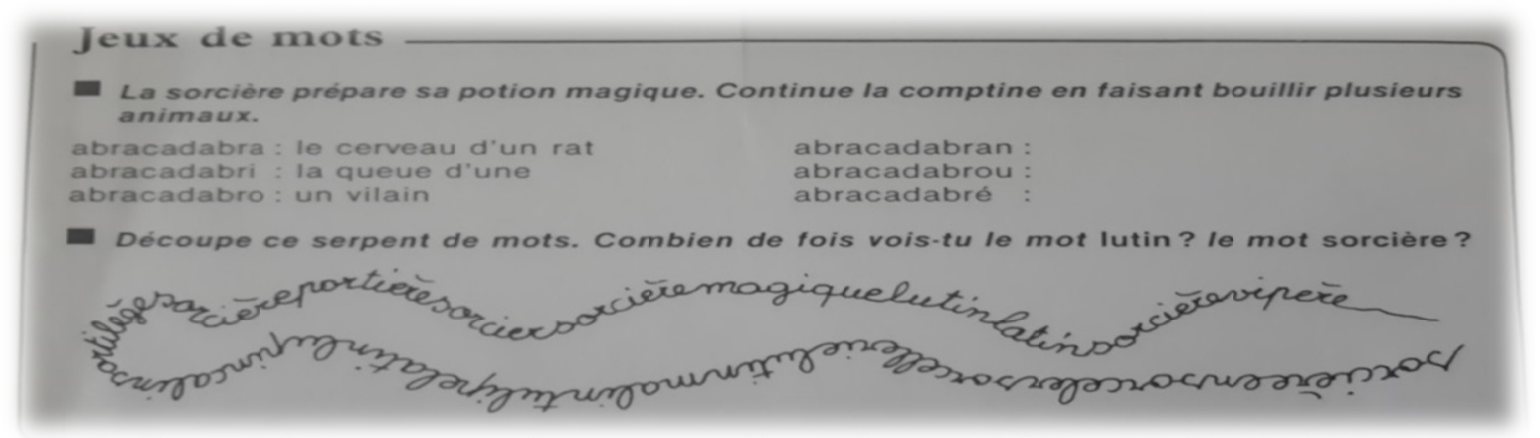

Picture 1. Document on mother tongue teaching with game in classroom in France

Game is the principal occupation of child he is amused at. Before expressing himself in oral mother tongue, language is the most important toy for the baby. At the beginning, he plays with language by enouncing uncertain sounds and maintains game activities with his peers together with his socialization and cognitive development. Game renders child creative and helps his physical, social, emotional and mental development. Thus, consulting games in primary school would be motivating in learning. Drama could be employed in learning mother tongue. Dramatic game is to make all individuals actively participate in amusing activities under the surveillance of teacher. Teacher like a wright determines the rules and boundaries of game and makes all students join them. When Turkish mother tongue teaching syllabus is examined, it is obvious that game plays an important role in teaching and teacher is strongly suggested to play games. However, it is possible to see some shortcomings in textbooks and in practice alike. Since teachers are not provided enough documents containing these traits, they are unable to contextualize in-class activities with game and know how to apply it in the classroom. Only those that are keen on learning are able to consult technology-based games on their own. It is highly difficult to say that textbooks of mother tongue teaching contain teaching models that could draw attention of child or motivate him in learning. Today's textbooks are more pedagogic than those prepared in the past. Game takes a great place in French textbooks. National Ministry of Education provides teachers with game documents for pedagogic teaching in classroom 


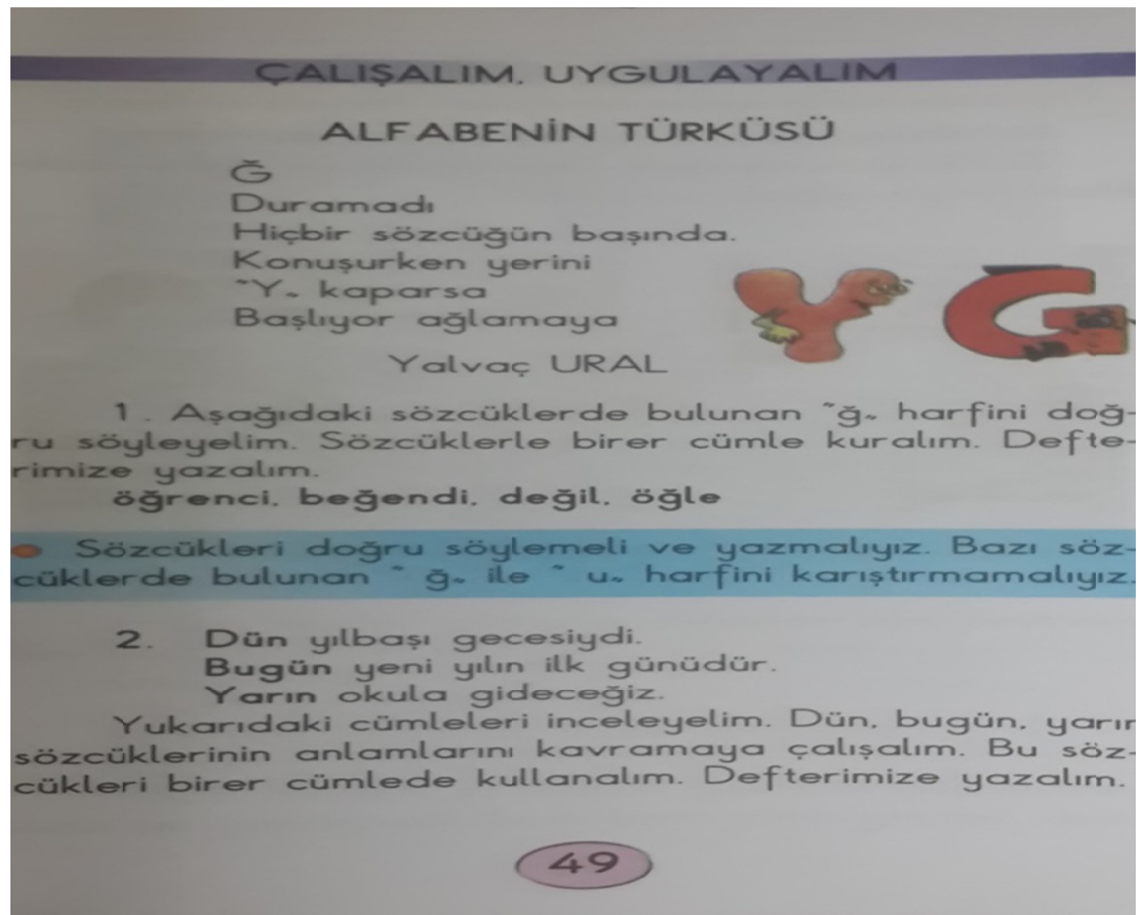

Picture 2. Teaching letters with their phonemes in Turkish mother tongue teaching textbook (Doğan et al. 2004)

In teaching reading and writing, games are the best way to increase achievement level (Keskinkılıç, 2005). Differences in textbooks prepared to teach mother tongue in two countries are evident. In both systems, mother tongue teaching is conducted based on phonemes but the textbooks in France are prepared accordingly while a different way is followed in theory and in practice in Turkey. In syllabus, phoneme based approach is adopted however; textbooks do not contain such a model. The first chapters of textbooks are full of reading texts while Turkish students do not know how to read and in addition phoneme based letter teaching is almost absent and pedagogic. In contrast, French textbooks involve phonemes of letters successively and explanations are in colour and given within a game framework.

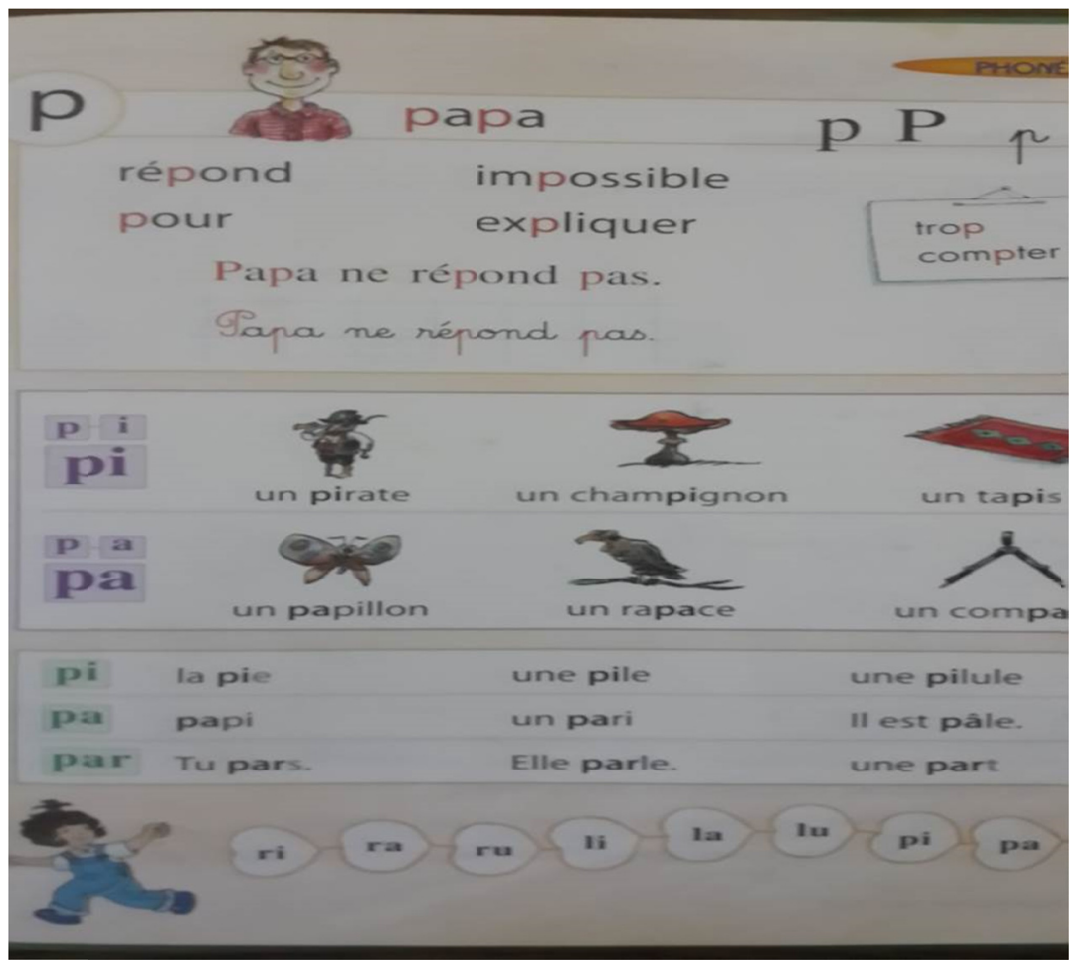

Picture 3. Teaching letters with their phonemes in French mother tongue teaching textbook (Youenne et al., 2000)

In order to get insight into teachers' views on mother tongue teaching at school, a questionnaire of six open-ended questions was administered. They were completed by 22 French and 23 Turkish teachers. They were filled out 
face-to-face by Turkish teachers and French teachers online. 13 French teachers were contacted in France while 9 of the teachers were communicated through an internet forum (plants cartable) and "survey monkey" application was used to interview them. The views of teachers are given in Table 1.

Assessing the views of both French and Turkish teachers on teaching mother tongue at school, we have found the differences of understanding, which results from social and cultural distinctions at various dimensions. For instance, team-work is important for French teachers while it is regarded as trivial by Turkish colleagues. Team-work for French teachers would induce employ among the people in a community, which is highly relevant for the development. Lacking such a trait, individuals would not seek to understand others but rather try to make them resemble themselves. This can be taken into consideration when it comes to mother tongue teaching with game and its evaluation. In both topics, the views of French teachers are universally accepted, which are not daily but more prospective. We can easily observe the reflections of mother tongue teaching with games on development of reading habits in France. Compared to Turkey, in France the rate of reading habit per person is quite higher. However, in Turkey evaluation has a crucial role in learning and students are not assessed based on their skills but on the scores they receive, which increases anxiety of score. Cultural differences in mother tongue are due to demographic structures of societies. French society is demographically multicultural. Having different ethnicities like Moroccan, Tunisian, Algerian and African and their cultures could lead to problems of learning their mother tongue at school. Though Turkish teachers do not dispose any view, cultural problems are also experienced. In particular, in regions where Kurds are dominant, they have difficulties of learning Turkish as a mother tongue due to the cultural and linguistic influence in their families.

Table 1. Views of Turkish and French Teachers on Mother Tongue Teaching at School

\begin{tabular}{|c|c|}
\hline \multicolumn{2}{|c|}{ 1- What are the positive aspects of phoneme based mother tongue teaching method? } \\
\hline Views of French Teachers & Views of Turkish Teachers \\
\hline It materializes teaching. Child seizes that letters have also phonemes. & It teaches mastering letters and phonemes of the language \\
\hline $\begin{array}{l}\text { It develops learner's problem solving skills. When he is taught only one } \\
\text { phoneme of one letter, he could learn the others on his own. }\end{array}$ & $\begin{array}{c}\text { It helps students learn reading and writing before their due } \\
\text { date. }\end{array}$ \\
\hline It keeps learner active in learning & It makes mother tongue teaching more amusing. \\
\hline It make students think critically & It helps majority of students participate in the class \\
\hline- & It helps students become competent in reading and writing \\
\hline \multicolumn{2}{|c|}{ What are the negative aspects of phoneme based mother tongue teaching method? } \\
\hline Views of French Teachers & Views of Turkish Teachers \\
\hline $\begin{array}{l}\text { It may cause some students to compare written and oral language. Speech is a } \\
\text { phonetic action. Since it is based on phonemes, student may search for the } \\
\text { same action in writing, as well. }\end{array}$ & It slows down reading. \\
\hline $\begin{array}{l}\text { It may prevent some students from finding out the relation between phoneme } \\
\text { and meaning }\end{array}$ & $\begin{array}{l}\text { It may impede fluent reading and in some cases student } \\
\text { reads spelling }\end{array}$ \\
\hline (25 & $\begin{array}{c}\text { Lack of material and textbooks is seen in applying the } \\
\text { method. }\end{array}$ \\
\hline & $\begin{array}{l}\text { Teaching written language, one may experience difficulties } \\
\text { in conjunction of letters and phonemes. }\end{array}$ \\
\hline \multicolumn{2}{|l|}{ What do you think about mother tongue teaching in groups? } \\
\hline Views of French Teachers & Views of Turkish Teachers \\
\hline It encourages team-work & $\begin{array}{l}\text { Grouping is not appropriate for development of students. } \\
\text { Individual work is more suitable for students }\end{array}$ \\
\hline Team-work skills are improved & $\begin{array}{l}\text { If individual differences are considered, it might be } \\
\text { beneficial. }\end{array}$ \\
\hline It improves employ & $\begin{array}{l}\text { It is difficult to form groups because of lack of physical } \\
\text { facilities }\end{array}$ \\
\hline \multicolumn{2}{|c|}{$\begin{array}{ll}\text { 4- } \quad \text { What do you think about mother tongue teaching with games? } \\
\end{array}$} \\
\hline Views of French Teachers & Views of Turkish Teachers \\
\hline It increases motivation of learner in learning. & $\begin{array}{l}\text { Game renders knowledge permanent and helps learner } \\
\text { learn more easily, participate actively in the class and seize } \\
\text { information better. }\end{array}$ \\
\hline Teaching with games would help child acquire reading habit & $\begin{array}{l}\text { Teaching with game makes it difficult complete the lessons } \\
\text { in the curriculum and in crowded classrooms, it is hard to } \\
\text { practice it. }\end{array}$ \\
\hline \multicolumn{2}{|c|}{ 5- How should mother tongue teaching be evaluated? } \\
\hline Views of French Teachers & Views of Turkish Teachers \\
\hline $\begin{array}{l}\text { Flexible evaluation should be considered. A more normative evaluation would } \\
\text { disincline student from learning. }\end{array}$ & $\begin{array}{l}\text { Students behavior should be observed and their work } \\
\text { should be assessed }\end{array}$ \\
\hline Outcome based evaluation is necessary. & - \\
\hline \multicolumn{2}{|c|}{ 6- What are the common problems of mother tongue teaching at school? } \\
\hline Views of French Teachers & Views of Turkish Teachers \\
\hline Individual differences among students & $\begin{array}{l}\text { Lack of material or appropriate material (textbooks are not } \\
\text { prepared in accordance with phoneme based method) }\end{array}$ \\
\hline Cultural problems & Indifference of parents \\
\hline- & $\begin{array}{l}\text { Students confusion of mother tongue's written and oral } \\
\text { dimension }\end{array}$ \\
\hline
\end{tabular}




\section{Conclusion and Suggestions}

Evaluating mother tongue teaching methods at school of two secular countries, similarities were found as well as a diversity of understanding in that respect. In fact, differences are exceeding similarities. The most conspicuous distinction is seen in the way mother tongue teaching is conducted. In Turkey, mother tongue learning starts in all its dimensions in the first grade at primary school while in France it begins in kindergarten and continues to be learned at primary school. French students complete introduction and foundations of reading and writing in kindergarten. Unlike in Turkey, in France students are preparations for listening, reading and writing, development of hand muscles, pen-holding, reading positions etc. are all taught at kindergarten. Therefore, students become ready for primary school. In addition, they become conscious of the importance of reading and writing for individuals when they are already at kindergarten. There is a harmonious integration between kindergarten and primary school in France, which makes French students precede their Turkish peers. In Turkey, since all activities related to mother tongue learning are completed as of primary school, students are not able to find time to get aware of lessons to be taught. French teachers possess more freedom in terms of methods of teaching mother tongue. Though phoneme based strategy is adopted based on individual differences in the classroom, they can also consult other methods like "sentence based and mixed method" at the same time as a method for teaching method would not be appropriate for all students. Turkish teachers are supposed to use only one method: phoneme based method. As to the sources used, French textbooks on teaching mother tongue have more pedagogical content and teachers are provided with more pedagogical sources accordingly.

French teachers state more positive opinions on in-class activities than their Turkish colleagues. French teachers believe that group-based mother tongue teaching would result in more adaptive children to society having a high level empathy. In this respect, they think of the future and have more universal views while Turkish teachers focus on more daily or momentary situation of mother tongue teaching complaining about the physical conditions of classrooms inappropriate for teaching in-groups. Teachers of both countries agree on teaching mother tongue with games. In terms of difficulties experienced in mother tongue teaching, French teachers suggest that they are due to individual and cultural differences while Turkish teachers complain about the lack of material and indifference of parents.

Turkey, candidate country for EU membership, which demonstrates progress in all areas from education to democracy, is in a better condition compared to the past. Its objective is to catch the level of France in mother tongue teaching at school and even override. Mother tongue teaching contributes to the development of their later years. For instance, French students grow up interpreting events critically and developing research skills with the effect of mother tongue teaching. The rate of literacy is higher in France than in Turkey as a result of mother tongue teaching.

When it comes to the writing dimension of mother tongue, it is not sufficient to know only reading. We live in an age when information is abundant and effective interpretation is obligatory. Therefore, reading must be fluent, strategic and life-long (Akyol, 2005). Fluent reading is like speaking and is a skill to distinguish words. Strategic reading is skimming of written material considering the level of difficulty that is to find a method. On the other hand, reading requires continuity, which can be improved by means of continuation. It is the writing dimension of mother tongue that develops oral language skills of individual. A person that reads all the time can find himself proficient in oral language and advances speaking skills. He enhances vocabulary and increases capacity to interpret and has a different perspective on the world.

\section{References}

Akyol, H. (2005). Türkçe İlk Okuma Yazma Öğretimi. Ankara: PegemA Yayıncılık.

Bernardin, J. (1997). Comment les enfants entrent dans la culture écrite. Paris: Editions RETZ.

Chao, Y. R. (1970). Langage et systemes symboliques. (Çev: Calvet, J.L.) Paris: Payot.

Delacroix, H. (1930). Le langage et la pensée. Paris: LibrairieFélix Alcan.

Doğan, S., Güden, M., Pınar, H., \& Demir, H. (2004). İlköğretim Ders Kitabı Türkçe 1. Eskişehir: 4. Akşam Sanat Okulu Matbaasi.

Fijalkow, J. (1999). Entrer Dans l'écrit. Belgique: EditionsMagnard.

Giordan, A. (1998). Apprendre. Paris: Editions Belin.

Giordan, A. (2002). Une Autre Ecole Pour Nos Enfants? Paris: EditionsDelagrave.

Giroux, S., \&Tremblay, G. (2002). Méthodologiedesscienceshumaines, la recherce en action. 2. Edition. Québec: Erpi.

Keskinkılıç, K.\&Keskinkılıç, S. B. (2005). Türkçe'nin Temel Becerileri ve Ses Temelli Cümle Yöntemi ile İlkokuma Yazma Öğretimi. Ankara: BRC Matbaacıllk.

Menf (ministère de l'éducation nationale française). (2004). Qu'apprend-on à l'école élémentaire. Paris: XO Editions. 
Sarıca, B. (2005). Ağız Çalışmalarının Dil Öğretimine Katkıları. Yeni Dilbilim Kuramları Işı̆̆ında Sözlü Dil Yapısı. İstanbul: Multilingual.

Saussure, F. (1967). Cours de linguistique générale. Paris: EditionsPayot.

Tok, Ş. (2001). İlk Okuma Yazma Öğretiminde Kullanılan Yöntemlerin Değerlendirilmesi. Kuram ve Uygulamada Eğitim Yönetimi Dergisi.

Tortup, R., Yıldırım, N., Tortup, M., \& Gültekin, F. (2005a). İlk Öğretim Birinci Sınıf Türkçe Ders Kitabı. İzmir: Top Yayıncilik.

Tortup, R., Yıldırım, N., Tortup, M., \& Gültekin, F. (2005b). Okuma Yazma Öğreniyorum. İzmir: Top Yayıncılık.

Tortup, R., Yıldırım, N., Tortup, M., \& Gültekin, F. (2005c). Türkçe Öğretimi Çalışma Kitabı. İzmir: Top Yayıncılık.

Yıldırım, A. \& Şimşek, H. (2000). Sosyal Bilimlerde Nitel Araştırma Yöntemleri. Ankara: Seçkin Yayıncılık ve Dağıtım.

Youenne, G., Isabelle, C., \& Laurent, S. (2000). Justine et Compagnie, Méthode de lecture Livre 1 and 2. Paris: Editions Belin. http://forum.planete-cartables.net/

\section{Copyrights}

Copyright for this article is retained by the author(s), with first publication rights granted to the journal.

This is an open-access article distributed under the terms and conditions of the Creative Commons Attribution license which permits unrestricted use, distribution, and reproduction in any medium, provided the original work is properly cited. 